OPEN ACCESS

Vol. 7, No. 1, April, 2019

Page. $1-43$

DOI: https://doi.org/10.21107/jaffa.v7i1.6184
JOURNAL OF AUDITING, FINANCE, AND FORENSIC ACCOUNTING (JAFFA)

E-ISSN: 2461-0607 ISSN: 2339-2886

https://journal.trunojoyo.ac.id/jaffa/index

\title{
DETERMINANT OF CORPORATE SOCIAL RESPONSIBILITY DISCLOSURE
}

\section{Nuraini Fifianti, Prasetyono}

Accounting Departement, Faculty of Economics and Business, University of Trunojoyo Madura

\section{Article Info:}

Received: 22 Oktober 2019

in revised form: 24 Oktober 2019

Accepted: 21 November 2019

Available Online: 19 December 2019

Keywords:

CSR, Company Size, Liquidity, Profitability

Corresponding Author:

Email: nurainififianti@gmail.com

\begin{abstract}
This research aims to analyze the effect of company characteristics on CSR (Corporate Social Responsibility) disclosure. This research was conducted at manufacturing companies listed on Indonesian Stock Exchange in 2014-2016. This research used purposive sampling method. The samples consisted 58 companies with a total of 174 observations. The characteristics of the company in this research were proxied by the company size, liquidity, and profitability. Data analysis technique used in the research was multiple linier regression analysis technique. Based on the result of the analysis, it can be concluded the company size variable affect CSR disclosure, while the liquidity, leverage, and profitability variables do not affect CSR disclosure
\end{abstract}

\begin{abstract}
Abstrak; Penelitian ini bertujuan untuk menganalisis pengaruh karakteristik perusahaan terhadap pengungkapan CSR (Corporate Social Responsibility). Penelitian ini dilakukan pada perusahaan manufaktur yang terdaftar di Bursa Efek Indonesia pada tahun 2014-2016. Penelitian ini menggunakan metode purposive sampling. Sampel terdiri dari 58 perusahaan dengan total 174 pengamatan. Karakteristik perusahaan dalam penelitian ini diproksi oleh ukuran perusahaan, likuiditas dan profitabilitas. Teknik analisis data yang digunakan dalam penelitian ini adalah teknik analisis regresi linier berganda. Berdasarkan hasil analisis, dapat disimpulkan variabel ukuran perusahaan mempengaruhi pengungkapan CSR, sedangkan variabel likuiditas, leverage, dan profitabilitas tidak mempengaruhi pengungkapan CSR.
\end{abstract}




\section{INTRODUCTION}

From an economic point of view, the company main objective is to obtain maximum profits without ignoring the social and environmental impacts that cause environmental damage, such as deforestation, air pollution, water pollution, and so on. Through CSR (corporate social responsibility) or commonly known as triple bottom line (economic, social, and environmental), it is expected that the companies will not only focus on financial issues but also pay attention to the social and surrounding environment (Santoso, 2012).

Various CSR activities in the companies have an impact on expenses, which in turn will reduce company profits. This is one of the company's goals, which is maximizing shareholder wealth that is operationalized by maximizing profits, so CSR seems inconsistent with these goals. Therefore, companies are not motivated to implement CSR (Darwin, 2007).

CSR is no longer voluntary/committed by the company in taking responsibility for the company's activities, but it is mandatory/obligation by several companies to perform it according to the provisions of Capital Markets Supervisory Board (BAPEPAM) (today is Financial Services Authority/OJK). The reason why companies implement CSR is to comply with the existing regulations.

CSR implementation by the companies can be actualized by corporate social responsibility disclosure that is revealed to the public in the company's annual report (Sari, 2012). CSR implementation is increasingly gaining attention from businessmen because it will increase social control and critical action from society regarding the problems of pollution, resources, waste, product quality, product safety level, as well as labor rights and status. Therefore, it forces the companies to take responsibility for their business's activity impact on society (Gray et al (1987) in Sudana et al, 2011).

Company size is a widely used variable to explain CSR implementation in company's annual report. Company size is related to agency theory, which states that large companies have more than small companies. Larger companies tend to have higher public demand for information than smaller companies. Research of Rindawati (2015), Agung and Ardhani (2015) stated that company size had no effect on CSR disclosure. However, this is different from the research by Fitri and Andi (2016), Santoso and Erline (2012), Amalia (2013), Khikmah (2011) and Fatoni, Rita, Andini (2016) which stated that company size affected CSR Disclosure.

Liquidity is used to measure company's willingness to fulfill its short-term obligations. According to Harahap (2007: 301), liquidity ratio illustrates company's ability to settle its short-term obligations. Several studies by Aulia and Wawo (2016), Kamil (2012), Masyitah (2016), and Wandayani and Sagara (2015) found that liquidity affected CSR disclosure. These studies are in contrast with the research conducted by Rafika and Yogi (2014) which stated that liquidity had no effect on CSR disclosure.

According to Kasmir $(2012,201) \mathrm{ROA}$ is a ratio that shows the return on assets used in the companies. Several studies conducted by Amalia (2013), Wahyu (2015), Wandayani and Sugara (2015) indicated that profitability affected CSR Disclosure. This is in contrast with the research of Nasir, Kurnia, Teguh (2013), Anggraini and Yogi (2014), and Ribut and Dewi (2014) which explained that profitability had no effect on CSR Disclosure.

\section{LITERATURE REVIEW AND HYPOTHESES DEVELOPMENT}

Stakeholders basically can control or have the ability to affect the use of economic resources by the company. Stakeholders can be divided into two based on their characteristics, primary and secondary stakeholders (Clarkson, 1995). Primary stakeholders are influential individuals or groups in the company, and without them the company cannot survive for going concern including: shareholders and investors, employees, customers and suppliers, alongside those defined as public stakeholder groups which are government and society. Secondary stakeholder groups are defined as those who affect, or those who are affected by the company, but they do not relate to the transactions with the company and their continuity is not essential. The stakeholder theory thinks that companies are not entities that only operate for their own interests, 
but also provide benefits for the stakeholders (Chariri, 2007). The main company objective is balancing the conflict among stakeholders.

This research used stakeholder theory, it is able to explain the relationship between the company and its stakeholders. Basically, stakeholders can control or have the ability to effect the use of economic resources by the company. Therefore, stakeholder power is determined by the size of the power owned by stakeholders over the source (Ghozali and Chariri, 2007).

\section{Company Size Effect on CSR Disclosure}

According to Halim (2007: 42), the larger the company size, the greater the tendency to use foreign capital. This condition occurs because large companies need large funds to support their operation, and the alternative is using foreign capital if their own capital is insufficient. Research by Santoso (2012) and Amalia (2013) indicated that company size had a significant effect on CSR disclosure, although this result is slightly different from Meita research (2015) which indicated that company size had no effect on CSR disclosure. Based on the theory and empirical result, we can make the following hypothesis: H1: Company size has a significant effect on CSR disclosure

\section{Liquidity Effect on CSR Disclosure}

According to Kasmir (2012: 129), "liquidity is a ratio to indicate or measure company's ability to meet the maturity obligations, both to external parties (business entity liquidity) and within the company (company liquidity)". Kartika (2010) concluded that the lower the level of corporate liquidity, the higher the social responsibility disclosure. Liquidity is one of the investor's benchmarks in assessing companies. Therefore, when the liquidity is lower, the company tends to implement corporate social responsibility disclosure. Research by Wandayani and Sagara (2015) indicated that liquidity ratios had a significant effect on CSR disclosure. While research by Sukenti, Hidayanti, and Mawardi (2016) indicated that liquidity had no effect on CSR disclosure. Based on the theory and the empirical research, the hypothesis is: H2: Liquidity has a significant effect on CSR disclosure

\section{Profitability Effect on CSR Disclosure}

Profitability is a factor that makes the management is free and flexible to express their accountability to shareholders, so, the higher the profitability, the greater the social information disclosure (Marbun, 2008 in Grace, Hutabarat, and Faradilla, 2010). The relationship between corporate social responsibility disclosure and company profitability has become a standard to illustrate the view that social responses require the same managerial style to be performed to make a company obtains a profit. Research by Amalia (2013) and Wahyu (2015) indicated that profitability affected CSR disclosure, but it was in contrast to a research conducted by Rafiqoh and Priyadi (2016) that indicated profitability (ROA) had no effect on CSR. Based on the theory theories and research result discussed, the hypothesis is: H3: Profitability has a significant effect on CSR Disclosure

\section{RESEARCH METHODOLOGY}

The data in this research was in the form of secondary data, which was in the form of financial statements and annual reports of manufacturing companies during the span of 3 years from 2014-2016. This data was obtained by accessing the Indonesia Stock Exchange official website (www.idx.co.id). The sampling technique was purposive sampling. From 137 manufacturing companies listed on the Indonesia Stock Exchange in 2014-2016, there were 58 companies that deserved to be analyzed. 


\section{FINDINGS AND DISCUSSION}

\section{Multiple Regression Analysis}

The use of this method is to determine the effects among two or more independent variables $(\mathrm{X})$, consisting of company size, liquidity, and profitability on the dependent variable $(\mathrm{Y})$, which is CSR disclosure. Based on the calculation from multiple linear regression model, the regression equation results ( $t$ test) can be found in Table 1 :

Tabel 1. Multiple Regression Analysis Results

\begin{tabular}{cccccc}
\hline Model & B & Std.Error & Beta & T & Sig \\
\hline (constant) & 0.115 & 0.010 & & 12.031 & 0.000 \\
Lag_Size & -0.004 & 0.001 & -0.273 & -3.584 & 0.000 \\
Lag_Cr & 0.000 & 0.002 & -0.015 & -0.187 & 0.852 \\
Lag_Roa & 0.018 & 0.019 & -0.073 & 0.939 & 0.349 \\
\hline
\end{tabular}

Source: IDX Processed 2018

The equation model in this research is:

$\mathrm{Y}=\beta+\beta 1$ Size $+\beta 2$ Current Ratio $+\beta 3$ ROA $+e$

Lag $Y=0.115-0.004$ LagSize +0.000 LagCR +0.018 LagROA

Description:

$\mathrm{Y}=$ corporate social responsibility

$\mathrm{B}=$ constant

$\beta 1, \beta 2, \beta 3, \beta 4=$ regression coefficient

$\mathrm{e}=$ error

it can be inferred from the results that:

a. The constant value was 0.115 , meaning that if $\beta 1, \beta 2, \beta 3, \beta 4$ did not increase, then $\mathrm{Y}$ variable was equal to 0,115 .

b. The value of regression coefficient on size variable on corporate social responsibility variable was -0.004 . It meant that an increase in size by one percent would decrease by -0.004 .

c. The value of regression coefficient in liquidity variable (CR) on corporate social responsibility was 0.000 . It meant that if liquidity increased by one unit, the CSR variable would increase by 0.000 .

d. The value of regression coefficient in ROA variable on corporate social responsibility was 0.018 . It meant that if ROA increased by one unit then the ROA variable would increase by 0.018 .

\section{T-test}

T-test is used to view the independent variable that is able to explain the dependent variable partially. The test criteria used aims to compare the value of $t$ count with $t$ table and compare the value of sig with $5 \%$ degree of confidence (0.05). The following are the results of t-test which are presented in Table 2 .

Table 2. T-Test Results

\begin{tabular}{cccc}
\hline Model & T & Sig & Description \\
\hline Size & -3.084 & 0.000 & Affect significantly \\
CR & -0.187 & 0.852 & Does not affect significantly \\
ROA & -0.939 & 0.349 & Does not affect significantly \\
\hline
\end{tabular}

Source: IDX Processed 2018 


\section{Discussion \\ Effect of Company Size on CSR Disclosure}

The result indicated that company size had a significant effect on CSR disclosure. In addition, the larger the company size, the higher the level of CSR that must be disclosed. This value proved that company responsibility was affected by company size. Here the larger the companies certainly disclosed more information. Larger companies had more operating activities and greater effect on society (Putri, 2017).

In addition, companies with a larger size were required to have high performance, so the companies pay more attention to the social environmental condition and perform social responsibility by disclosing greater CSR. Moreover, it was likely that the greater number of shareholders would always pay attention to the social programs created by the company. The result was in accordance with stakeholder theory, in which the greater the company size, the greater stakeholder's demands for the benefits. The larger a company, the greater the corporate social responsibility disclosure (Yusuf, 2011).

The result was in line with Rafiqoh and Maswar (2016), and Wijaya (2012) that company size had an effect on CSR disclosure. Whereas, the research by Meita (2015) indicated that the company size had no effect on CSR disclosure.

\section{Effect of Liquidity on CSR Disclosure}

The result proves that liquidity (CR) had no effect on CSR disclosure. The high or low level of a company's liquidity did not affect CSR disclosure quality. As revealed by Kamil \& Herusetya (2012), due to the lack of attention from investors on financial information, and did not take into account the liquidity quality of the entity, liquidity only slightly affected the CSR. In addition, if company liquidity level was higher, CSR disclosure was lower because the high level of company liquidity would make the company think to pay its debt rather than to perform CSR. Liquidity was seen by the market as a performance measure (Rahmawati, 2010).

Moreover, CSR was no longer a mere activity, so the company would disclose its corporate social responsibility as stipulated in Law No. 40 of 2007. CSR disclosure by a company was useful to maintain company survival, so the high or low level of a company's liquidity did not affect CSR disclosure level (Rosmasita, 2007).

The result was in line with Ristanto et al (2017), Hillary \& Nicken (2017), and Sri et al (2016) who stated that liquidity affected CSR disclosure. Whereas, this research rejected a research by Putri (2017) which stated that liquidity affected CSR disclosure.

\section{Effect of Profitability on CSR Disclosure}

The result proved that profitability (ROA) did not affect CSR Disclosure. So, the high or low level of a company's liquidity did not affect CSR disclosure level. The result was not in accordance with the legitimacy theory stating that the greater the profitability or profits, the greater the corporate social responsibility disclosure level.

Other possible reason was the assumption that corporate social responsibility disclosure was an unfavorable activity for the company, mainly for profit-oriented companies. When a company had a high level of profitability, the companies considered that there was no need to increase the disclosure cost or added social action just because it was their responsibility. When a company had a low profitability level, it tended to minimize the expenses to perform CSR disclosure (Sumilat 2017). Company profitability did not always have an effect on corporate social responsibility because the company did not always obtain profits. Companies with high profitability did not necessarily have to carry out social activities because they were more profit oriented. When the companies obtained higher profits, the (management) did not necessarily have to report the things that interfered the information about the success of company finance. However, when a company obtained a loss or a lower profitability level, the company expected that the report users would read "a good news" about the company performance. It could be in the form of environmental social activities conducted by the company. This research showed that company size would not affect the corporate social responsibility level (Agung, 2015).

The result was in line with Suci, et al (2017), Wandayani and Yasar (2015), and Virgia (2017) who stated that profitability had no significant effect on corporate social 
responsibility disclosure. However, the result rejected Chasana (2017) and Agung (2015) research which stated that profitability had a significant effect on corporate social responsibility disclosure.

\section{CONCLUSION AND SUGGESTIONS}

Company size has an effect on CSR disclosure. This is because the company size will affect the corporate social responsibility disclosure. The greater the assets owned by the company, the greater the demands to give a good performance. Profitability has no effect on CSR disclosure. It occurs because companies do not always obtain profits. Companies with high profitability do not necessarily have to conduct social activities since their orientation is profit.

Issuers should help in considering the creation of corporate social responsibility, because nowadays the corporate social responsibility has become a necessity that will affect the survival of the company and society in the future. The results here are expected to provide benefits for the investors or prospective investors to consider the investment decision making that are not only based on business profit, but also company's concern for the society and nature. Financial Services Authority (OJK in Indonesia) and IDX as government agencies in giving guidance, regulation, and supervision, are expected to pay more attention to the companies listed in the IDX, in order to perform CSR disclosure for the social welfare of society and company. Further researchers are expected to use other extensive variables to obtain more accurate input regarding corporate social responsibility disclosure, such as variable of profit management, management ownership, industry type, etc., and conduct research using other sub-sectors listed on the IDX as well as add the research period.

\section{REFERENCES}

Amalia, Dewi. 2013. Pengaruh Karateristik Perusahaan Terhadap Corporate Social Responsibility Disclosure di Bursa Efek Indonesia. Media Riset Akuntansi. Vol 3, No 1.

Anggraini, Fr. R. R. 2006. Pengungkapan Informasi Sosial dan Faktor-Faktor yang Mempengaruhi Pengungkapan Informasi Sosial dalam Laporan Tahunan Keuangan Tahunan. Simposium Nasional Akuntansi IX.

Darwin, A. 2007. Penerapan Sustainability Reporting di Indonesia. Konvensi Akuntansi V, Program Profesi Lanjutan. Yogyakarta.

Fahmi, I. 2013. Pengantar Manajemen Keuangan Teori dan Soal Jawab. Bandung : Alfabeta.

Gray et al, 1995. Corporate social and enviromental reporting; a review literature and longitudinal study of $u k$ disclosure. Scotland: Accounting, Auditing, and Accountability Journal. Vol 8 No.2 1995. Pp 47-77.

Harahap, S.S. 2007. Teori Akuntansi. Jakarta : Raja Grafindo Persada

Kamil, Ahmad Dan Herusetya, Antonius. 2014. Pengaruh Karateristik Perusahaan terhadap Luas Pengungkapan Kegiatan Corporate Social Perusahaan. ISSN: 20882106.

Kasmir, 2013. Analisis Laporan Keuangan. PT. Raja Grafindo, Persada. Jakarta.

Prastowo D, Dan R. Juliaty. 2005. Analisis Laporan Keuangan Konsep dan Aplikasi. Upp. Amp. YKPN-Yogyakarta.

Prima, S. Dan Keni. 2013. Pengaruh Umur Perusahaan, Profitabilitas, Ukuran Perusahan dan Leverage Terhadap Pengungkapan Tanggung Jawab Sosial Perusahaan Pada Perusahaan yang Terdaftar di BEI. Jurnal Ekonomi Universitas Tarumanegara. Vol 15, No 1, Hal 1-29.

Santoso, Linda Dan Chandra, Erline. 2012. Pengaruh Profitabilitas, Ukuran Perusahaan, Leverage, Umur Perusahaan, dan Dewan Komisaris Independen dalam Pengungkapan Corporate Social Responsibility. Jurnal Bisnis dan Akuntansi. Vo. 14, No. 1. 
Sari, R.A. 2012. Pengaruh Karateristik Perusahaan dan Pengungkapan Corporate Social Responsibility Disclosure. Pada Perusahaan Manufaktur yang Terdaftar di BEI. Jurnal Nominal. Vol. 1, No. 1.

Sartono, Agus. 2001. Manajemen Keuangan Teori dan Aplikasi. Yogyakarta. BPFEyogyakarta.

Sudana, I.M dan Putu A.A.W. 2011. Corporate Governance dan Pengungkapan Corporate Social Responsibility pada Perusahaan Go Public di BEI. Jurnal Manajemen Teori dan Terapan, April, Tahun 4.

Sugiyono. 2014. Metode Penelitian (Pendekatan Kuantitatif, Kualitatif, dan R\&D). Bandung. Alfabeta.

Undang-Undang Republik Indonesia No.40 Tahun 2007 Tentang Perseroan Terbatas. www.idx.co.id 